\title{
Influence of Detonation-Spraying Parameters on the Phase Composition and Tribological Properties of $\mathrm{Al}_{2} \mathrm{O}_{3}$ Coatings
}

\author{
Nurgamit Kantay ${ }^{1,2}$, Bauyrzhan Rakhadilov ${ }^{1, *}$, Sherzod Kurbanbekov ${ }^{3}$, Didar Yeskermessov ${ }^{2}$, \\ Gulnara Yerbolatova ${ }^{2}$ and Akbota Apsezhanova ${ }^{2}$ \\ 1 Research CenterSurface, Engineering and Tribology, Amanzholov University, \\ Ust-Kamenogorsk 070000, Kazakhstan; nurgan85@mail.ru \\ 2 The Faculty of Basic Engineering Training, Daulet Serikbaev East Kazakhstan Technical University, \\ Ust-Kamenogorsk 070000, Kazakhstan; didar.eskermesov@mail.ru (D.Y.); e.gulnara_77@mail.ru (G.Y.); \\ bota_ak92@mail.ru (A.A.) \\ 3 Department of Physics, Khoja Akhmet Yassawi International Kazakh-Turkish University, \\ Turkestan 161200, Kazakhstan; sherzod.kurbanbekov@ayu.edu.kz \\ * Correspondence: rakhadilovb@mail.ru; Tel.: +775-668-62-39
}

check for updates

Citation: Kantay, N.; Rakhadilov, B.; Kurbanbekov, S.; Yeskermessov, D.; Yerbolatova, G.; Apsezhanova, A. Influence of Detonation-Spraying Parameters on the Phase Composition and Tribological Properties of $\mathrm{Al}_{2} \mathrm{O}_{3}$ Coatings. Coatings 2021, 11, 793. https:// doi.org/10.3390/coatings11070793

Academic Editor: Shih-Chen Shi

Received: 26 May 2021

Accepted: 29 June 2021

Published: 30 June 2021

Publisher's Note: MDPI stays neutral with regard to jurisdictional claims in published maps and institutional affiliations.

Copyright: (c) 2021 by the authors. Licensee MDPI, Basel, Switzerland. This article is an open access article distributed under the terms and conditions of the Creative Commons Attribution (CC BY) license (https:/ / creativecommons.org/licenses/by/ $4.0 /)$.

\begin{abstract}
Al}_{2} \mathrm{O}_{3}$ coatings were applied on the surface of $12 \mathrm{Ch} 18 \mathrm{~N} 10 \mathrm{~T}$ steel by the detonation method at different degrees of filling of the detonation gun. The aim was to study the influence of technological parameters on the formation of the coating's structure, phase composition and tribological characteristics. The degree of filling the gun with a gas mixture $\left(\mathrm{C}_{2} \mathrm{H}_{2} / \mathrm{O}_{2}\right)$ varied from $53 \%$ to $68 \%$. X-ray diffraction study showed that the content of $\alpha-\mathrm{Al}_{2} \mathrm{O}_{3}$ increases depending on the degree of filling. The results showed that the hardness increases with an increase in the $\alpha-\mathrm{Al}_{2} \mathrm{O}_{3}$ phase. When the gun is $53 \%$ filled with gas, the $\mathrm{Al}_{2} \mathrm{O}_{3}$-based coating has the hardness of $20.56 \mathrm{GPa}$ compared to $58 \%, 63 \%$ and $68 \%$ fillings. Tribology tests have shown that the wear rate and friction coefficient of the coating is highly dependent on the degree of filling of the gun.
\end{abstract}

Keywords: detonation spray; coatings; aluminum oxide; microstructure; phase; micro-hardness; friction coefficient

\section{Introduction}

Engineering materials often undergo to the mechanical stress, heat radiation and/or corrosive environments. Taking this into account, not only new materials but the technologies have also been developed improving the performance of existing materials. The service life of machine parts and mechanisms can be extended by applying protective coatings or modifying the surface layer. One of the promising technologies is thermal spraying. Gas-thermal methods made it possible to obtain high quality, durable coatings [1-7]. For example, detonation spraying (DS) and high velocity oxygen-fuel (HVOF) spraying provide excellent adhesion strength, low porosity and a tough, dense and wear-resistant coating [8-10]. In addition, detonation spraying has the highest adhesion strength with the base material and the lowest porosity of the coating in comparison with other methods of gas-thermal spraying $[11,12]$. In this case, the quality of detonation coatings depends on the surface roughness of the substrate material and the chemical composition of the powder, the size of the granules, the ratio of gases and impurities [13]. With detonation spraying, coatings can be obtained from any materials, refractory compounds, oxides, etc. $\mathrm{Al}_{2} \mathrm{O}_{3}, \mathrm{WC}-\mathrm{Co}, \mathrm{NiCrBSi}$ and $\mathrm{Cr}_{3} \mathrm{C}_{2}-\mathrm{NiCr}$ are used to obtain wear-resistant coatings in order to restore parts.

$\mathrm{Al}_{2} \mathrm{O}_{3}$-based coatings are widely used to protect machine parts, boiler components, chemical and medical equipment, aircraft engine components, onshore and offshore turbines, etc. The final results of the research can be used in these areas. The powder of $\alpha-\mathrm{Al}_{2} \mathrm{O}_{3}$ is usually used for detonation coatings. However, the coatings obtained by the detonation method mainly consist of the $\gamma-\mathrm{Al}_{2} \mathrm{O}_{3}$ phase. The $\gamma-\mathrm{Al}_{2} \mathrm{O}_{3}$ is formed because of 
rapid crystallization of the molten sample [14]. The content of $\alpha-\mathrm{Al}_{2} \mathrm{O}_{3}$ in coatings after detonation spraying depends on the presence of insoluble or semi-soluble particles in the powder. Therefore, the structural-phase states of coatings based on aluminum oxide strongly depend on the technological mode of detonation spraying $[15,16]$.

The aim of this research was to study the effect of filling degree of a detonation gun on the phase composition and tribological properties of detonation coatings of aluminum oxide.

\section{Materials and Methods}

Detonation coatings were obtained using the detonation spraying complex CCDS2000 (LIH SB RAS, Novosibirsk, Russia) [17,18]. Figure 1 shows a general view and diagram of the detonation injection process. The gun is filled with gases using a high-precision gas distribution system and is controlled by a computer. The process begins by filling the gun with carrier gas. Then a certain part of the explosive mixture is feed to form a layered gaseous medium, consisting of an explosive charge and a carrier gas. The powder is poured into the explosion zone with the carrier gas flow and forms a cloud (fog). The spray gun is placed at a certain distance from the barrel and the computer beeps to initiate the explosion. This is done with an electric spark. The duration of the explosive combustion of the charge is about $1 \mathrm{~ms}$. A detonation wave is generated in the explosive mixture, which turns into a shock wave in the carrier gas. Detonation products (heated to $3500-4500 \mathrm{~K}$ ) and carrier gas (heated to 1000-1500 K by shock waves) move at a speed exceeding the speed of sound. The reaction time of gases with scattered particles is $2-5 \mathrm{~ms}$. The particle velocity can reach $800-1200 \mathrm{~ms}^{-1}[19,20]$. The consumption of working gases at the average frequency of shots of $4 \mathrm{~Hz}$ is: acetylene 4-7; propane butane mixture 2-3, 5; oxygen 10-12; nitrogen $10-15 \mathrm{~m}^{3} / \mathrm{h}$. Nitrogen was used as a carrier gas.

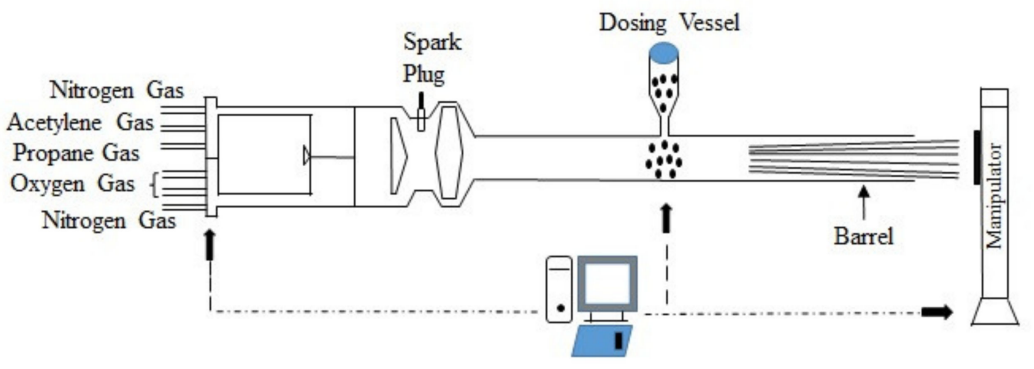

Figure 1. The diagram of CCDS2000 detonation complex.

The detonation spraying method was used to obtain $\mathrm{Al}_{2} \mathrm{O}_{3}$ coating. The size of the initial aluminum powder for spraying was $34 \pm 6 \mu \mathrm{m}$. The injector was placed on a CCDS2000 detonation unit with a diameter of $20 \mathrm{~mm}$ and a length of $800 \mathrm{~mm}$. Stainless $12 \mathrm{Ch} 18 \mathrm{~N} 10 \mathrm{~T}$ steel was selected as the substrate material. The chemical composition of the steel corresponds to GOST 4986-79 [21].

The dimensions of the steel samples were $75 \mathrm{~mm} \times 50 \mathrm{~mm} \times 5 \mathrm{~mm}$ and the surface roughness was $R_{\mathrm{a}}=0.088 \mu \mathrm{m}$. The surface was cleaned with electrocorundum (Contracor Eco140S, Wuppertal, Germany) with a grain size of about 20-80 microns, and the roughness of the substrate was about 4-4.5 microns. The surface was chemically wiped for 5-7 minutes and the substrate was dried for 20-30 min, then coated with $\mathrm{Al}_{2} \mathrm{O}_{3}$ powder. Table 1 shows the chemical composition of 12Ch18N10T steel.

Table 1. Chemical composition of 12Ch18N10T steel (AISI 321).

\begin{tabular}{ccccccccccccc}
\hline $\mathbf{C}$ & $\mathbf{S i}$ & $\mathbf{M n}$ & $\mathbf{P}$ & $\mathbf{S}$ & $\mathbf{C r}$ & $\mathbf{M o}$ & $\mathbf{N i}$ & $\mathbf{V}$ & $\mathbf{T i}$ & $\mathbf{C u}$ & $\mathbf{W}$ & $\mathbf{F e}$ \\
\hline$<0.12$ & $<0.8$ & $<2.0$ & $<0.035$ & $<0.02$ & $\begin{array}{l}17.0- \\
19.0\end{array}$ & $<0.5$ & $\begin{array}{c}9.0- \\
11.0\end{array}$ & $<0.2$ & $<0.8$ & $<0.4$ & $<0.2$ & $\begin{array}{c}\text { The } \\
\text { rest }\end{array}$ \\
\hline
\end{tabular}


The thickness of the coatings was $180 \mu \mathrm{m}$. The average size of the formed coating in a single shot was 8-10 $\mu \mathrm{m}$. Each sample was shot 20 times. The aluminum oxide coating was obtained by detonation spraying with different filling volumes (53\%, 58\%, $63 \%, 68 \%$ ). Depending on the volume of gas filling the barrel in the detonation device, the degree of explosion will be different, i.e. the larger the gas filling volume, the higher the explosion power at the same gas ratios. The power of the explosion also depends on the type of gases used and their ratio [22,23]. Experimentally, we have found that when the filling volume is below $50 \%$, the sprayed powder does not have a sufficient speed and temperature. During spraying, with a filling volume of $35 \%-45 \%$, some of the powders are not applied and, hitting to the surface of the substrate, are pushed back. In order for spraying to occur, the powders must partially or completely melt and have a fixed speed depending on the size of the powder. Taking into account the above and the technical characteristics of the detonation installation (maximum filling volume up to 70\%), We carried out experiments with filling volumes of 53\%,58\%,63\% and $68 \%$. In [24] it is shown that a changing in the technological modes of spraying, in particular, the frequency of spraying, leads to a changing in the phase composition, ie. changes in the content of $\alpha-\mathrm{Al}_{2} \mathrm{O}_{3}$ and $\gamma-\mathrm{Al}_{2} \mathrm{O}_{3}$. Such changes make it possible to obtain gradient coatings, where the content of $\alpha-\mathrm{Al}_{2} \mathrm{O}_{3}$ and $\gamma-\mathrm{Al}_{2} \mathrm{O}_{3}$ is adjusted in depth. Therefore, in this work, we studied the effect of the filling volume on the structure-phase states and tribological properties of coatings. Research data in the future allows to obtain gradient coatings by changing the filling volume during spraying.

Acetylene-oxygen mixture was used as a combustion gas. We chose $\mathrm{O}_{2} / \mathrm{C}_{2} \mathrm{H}_{2}=1.856$ as the optimal ratio to ensure complete melting of the powder. Table 2 shows the process parameters.

Table 2. Technological parameters of $\mathrm{Al}_{2} \mathrm{O}_{3}$ coating.

\begin{tabular}{ccccc}
\hline № & $\mathbf{O}_{\mathbf{2}} / \mathbf{C}_{\mathbf{2}} \mathbf{H}_{\mathbf{2}}$ & Barrel Filling, $\%$ & Spraying Distance, $\mathbf{m m}$ & Number of Shots \\
\hline 1 & 1.856 & 53 & 250 & 20 \\
2 & 1.856 & 58 & 250 & 20 \\
3 & 1.856 & 63 & 250 & 20 \\
4 & 1.856 & 68 & 250 & 20 \\
\hline
\end{tabular}

The distance between the barrel and the substrate was $250 \mathrm{~mm}$. The surface of the substrate was subjected to sandblasting and dry cleaning for 5-7 min. The sand with a grain size of about 40-60 $\mu \mathrm{m}$ was used to increase the average roughness of the dried sample to $4.5 \mu \mathrm{m}$.

The phase composition of the coatings was determined by X-ray diffraction (XRD) on an X'Pert PRO diffractometer (Philips Corporation, Amsterdam, the Netherlands) with $\mathrm{Cu}-\mathrm{K} \alpha$ radiation $(\lambda=1.541 \AA)$ at a voltage of $40 \mathrm{kV}$ and a current of $30 \mathrm{~mA}$. Diffraction patterns were decoded using the "High Score" software; measurements were carried out in the $2 \theta$ range, equal to $10^{\circ}-90^{\circ}$, with a step of 0.02 and a counting time of $0.5 \mathrm{~s} / \mathrm{step}$. The surface roughness was evaluated in accordance with GOST 2789-73 (ASTM D7127-05) [25] by the $R_{\text {a }}$ parameter using a profilometer model 130 (JSC Plant PROTON, Moscow, Russia). The surface of the coatings was examined at optical magnification of $\times 20$ using Altami MET 5S metallographic microscope (Altami LLC, St. Petersburg, Russia). The mechanical properties of the coatings (micro-hardness) were studied using PMT-3M micro-hardness tester (LOMO, St. Petersburg, Russia). Micro-hardness was measured according to GOST 9450-76 (ASTM E384-11) [26] at a maximum load of $3 \mathrm{~N}$ and a holding time of $10 \mathrm{~s}$.

Tribological properties were assessed in dry slip tests using TRB-3 high temperature tribometer (Anton Paar Srl, Peseux, Switzerland) by a standard ball-disc technique in accordance with ASTM G 133-95 and ASTM G99 [27,28]. The sliding pair was a stationary ball with a diameter of $6 \mathrm{~mm}$ and a hardness of $62 \pm 2 \mathrm{HRC}$, made of 100Cr6 steel. Pressed against a rotating disk made of 12Ch18N10T steel, respectively, without a coating and with a sprayed coating of $\mathrm{Al}_{2} \mathrm{O}_{3}$. The contact load was $10 \mathrm{~N}$ and a sliding speed was $0.2 \mathrm{~m} / \mathrm{s}$. The cycle time was $60 \mathrm{~min}$. The tribological properties of the coatings were characterized 
by the wear rate and the coefficient of friction. To obtain reliable research results and to discuss the results, a test was carried out on three samples from each batch.

\section{Results and Discussions}

Figure 2 shows the structure of the substrate surface and $\mathrm{Al}_{2} \mathrm{O}_{3}$ powder after detonation injection using an optical microscope. Figure 3 shows the microstructure of the surface layer of the $\mathrm{Al}_{2} \mathrm{O}_{3}$ coating by scanning electron microscopy. According to the Figure 2, we see that the granules in the surface layer of steel $12 \mathrm{Ch} 18 \mathrm{~N} 10 \mathrm{~T}$ are large (coarse), and the surface layer of the $\mathrm{Al}_{2} \mathrm{O}_{3}$ coating is small (fine grained).
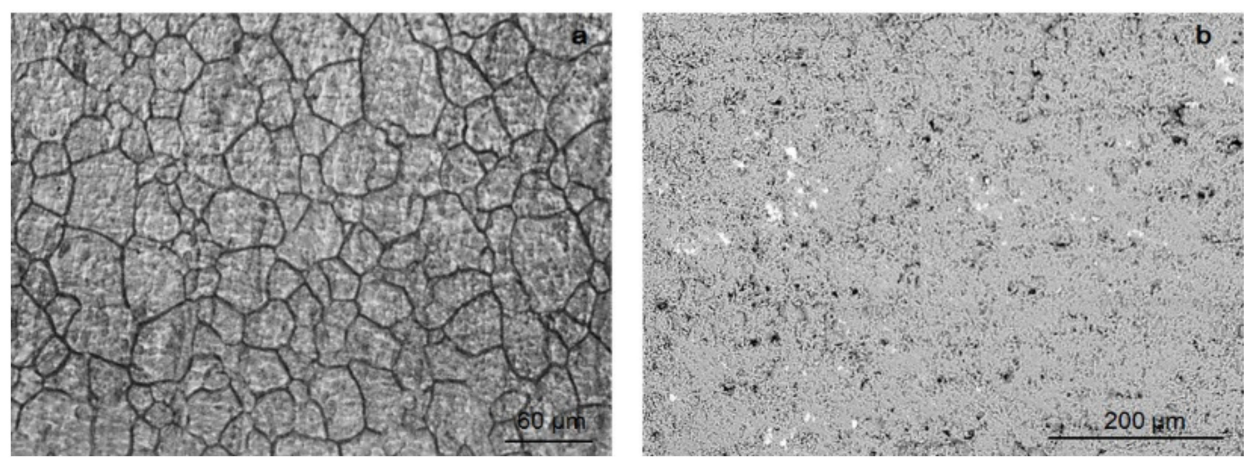

Figure 2. Surface structure of the substrate and structure of the surface after detonation spraying with $\mathrm{Al}_{2} \mathrm{O}_{3}$ powder: steel $12 \mathrm{Ch} 18 \mathrm{~N} 10 \mathrm{~T}(\mathbf{a}), \mathrm{Al}_{2} \mathrm{O}_{3}$ coating (b).

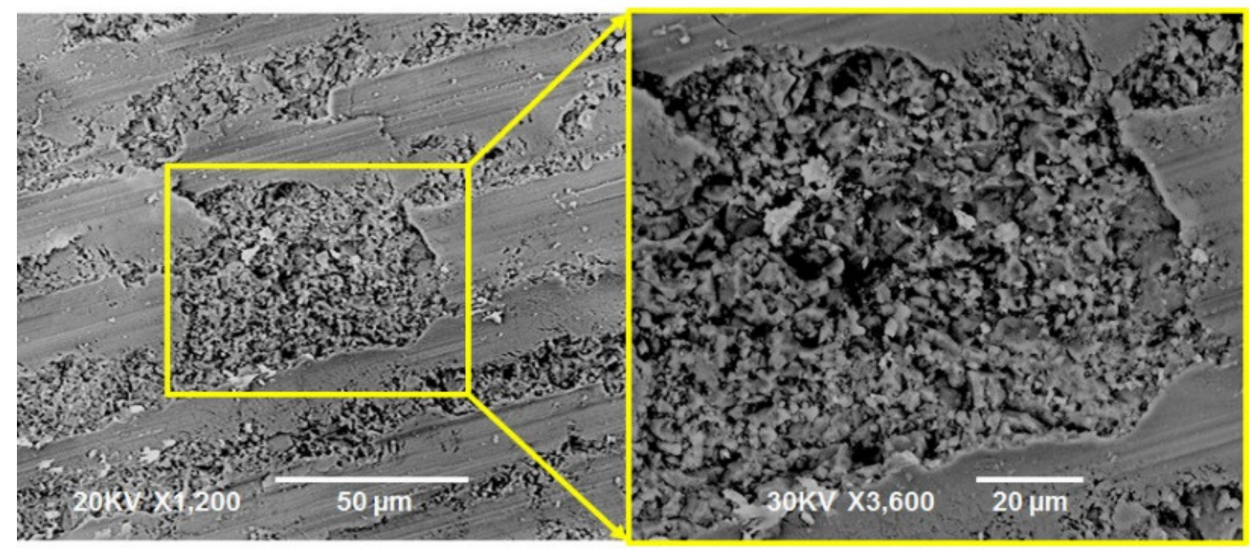

Figure 3. SEM image taken from the surface of the $\mathrm{Al}_{2} \mathrm{O}_{3}$ coating.

Figure 4 shows a graph of the microstructure and surface roughness, taken from the cross-section of the $\mathrm{Al}_{2} \mathrm{O}_{3}$ coating, depending on the volume of filling the barrel with gas $53 \%, 58 \%, 63 \%$ and $68 \%$. $R_{\mathrm{a}}$ values of all coatings ranged from 0.439 to $1.442 \mu \mathrm{m}$. This shows that the degree of barrel filling does not greatly affect the roughness of $\mathrm{Al}_{2} \mathrm{O}_{3}$ coatings.

Figure 5 shows SEM image taken from the cross section of the $\mathrm{Al}_{2} \mathrm{O}_{3}$ coating when $53 \%$ of the barrel is filled with gas, and Figure 6 shows the results of spectral microanalysis. According to Figure 6, the coating is dense and uniform, as well as the composition of the coating in the spectrum $001-005$ consists of pure $\mathrm{Al}$ and $\mathrm{O}$ atoms, as well as in the spectrum 006 taken from the boundary of the substrate and the coating, it was observed that the substrate material contains $\mathrm{Fe}, \mathrm{Cr}, \mathrm{Ni}$ atoms and the coating contains $\mathrm{Al}$ and $\mathrm{O}$ atoms. 


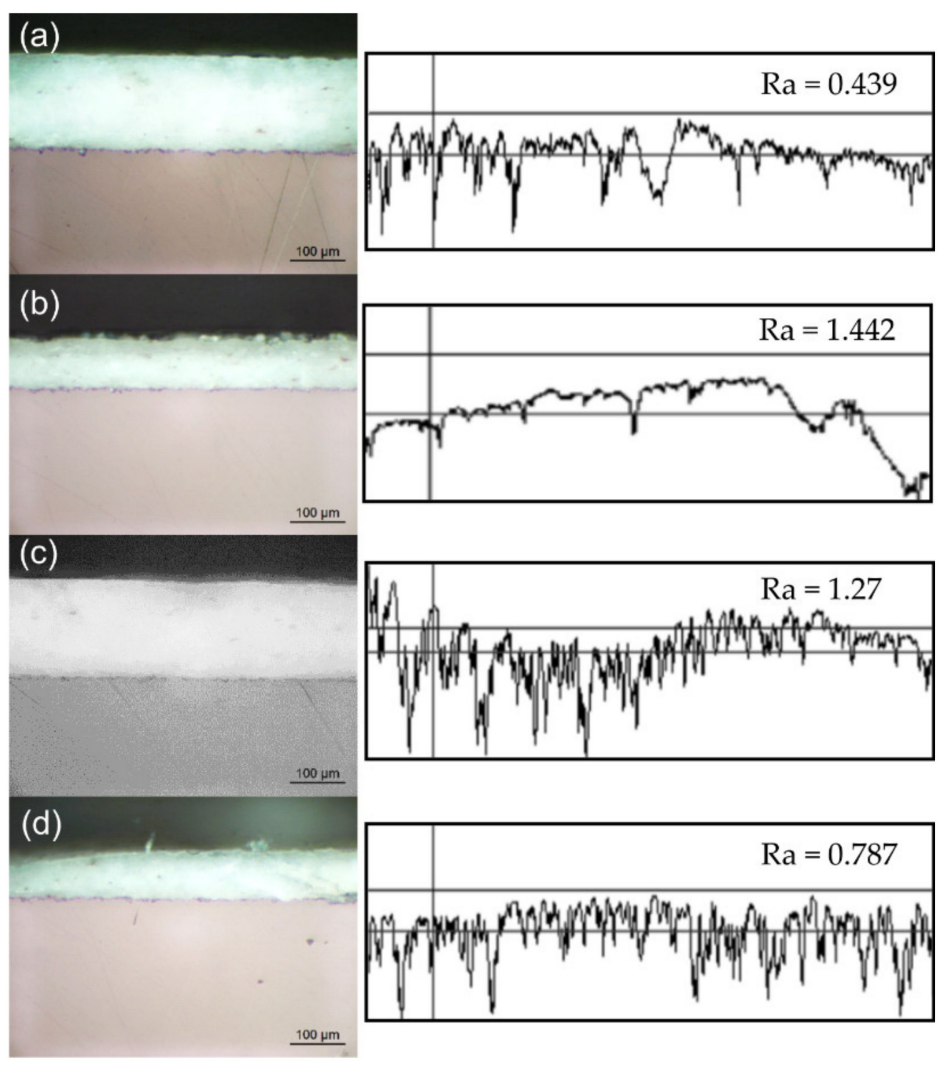

Figure 4. Depending on the volume of gas filling of the barrel the microstructure of the cross section of the $\mathrm{Al}_{2} \mathrm{O}_{3}$ coating and the surface roughness curve: $53 \%(\mathbf{a}), 58 \%(\mathbf{b}), 63 \%(\mathbf{c}), 68 \%(\mathbf{d})$.
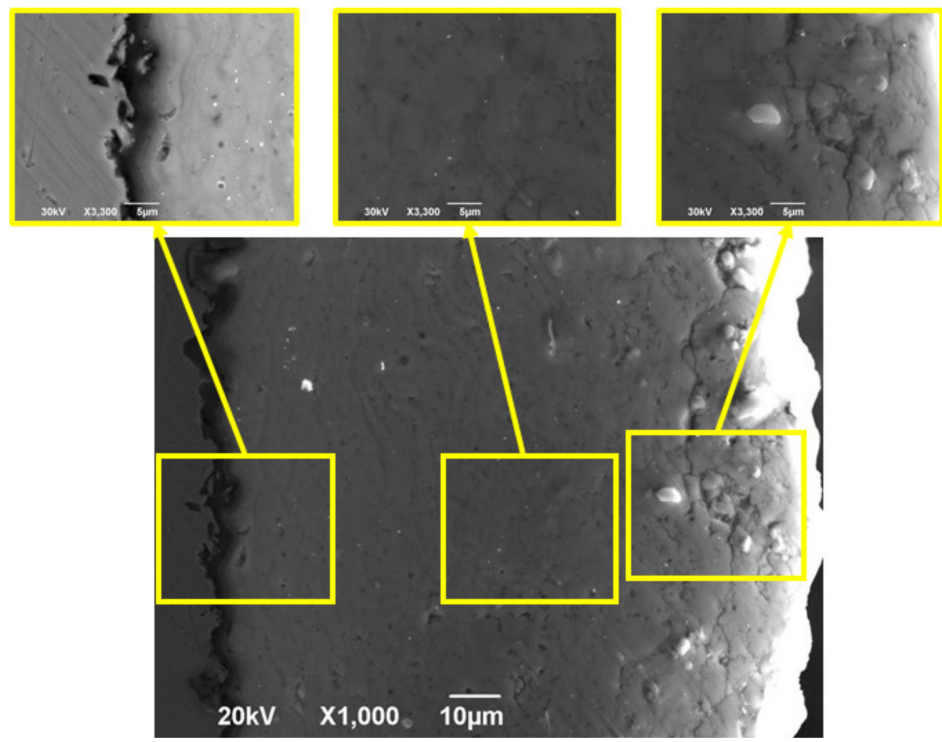

Figure 5. SEM image taken from the cross section of the $\mathrm{Al}_{2} \mathrm{O}_{3}$ coating when $53 \%$ of the barrel is filled with gas. 


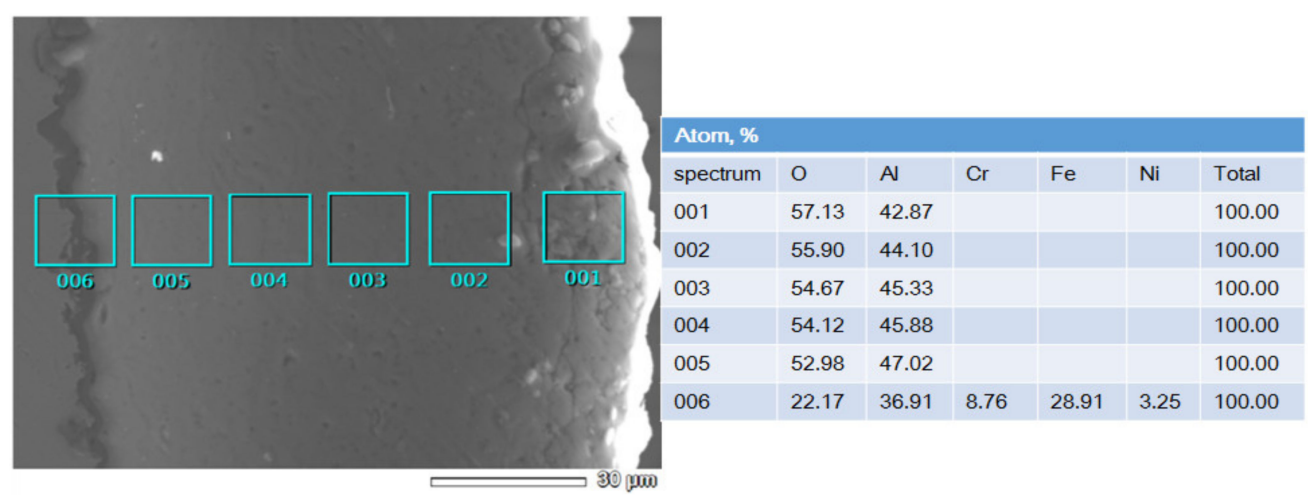

Figure 6. Spectral microanalysis of the cross section of the $\mathrm{Al}_{2} \mathrm{O}_{3}$ coating at $53 \%$ barrel gas filling.

Figure 7 shows the diffraction patterns of $\mathrm{Al}_{2} \mathrm{O}_{3}$ coatings obtained at $53 \%, 58 \%$, $63 \%$, and $68 \%$ barrel filling. The coatings after detonation spraying are composed of $\alpha-\mathrm{Al}_{2} \mathrm{O}_{3}$ (ICDD/JCPDS No. 96-230-0376) and $\gamma-\mathrm{Al}_{2} \mathrm{O}_{3}$ (ICDD/JCPDS No. 96-154-1583). Corundum $\alpha-\mathrm{Al}_{2} \mathrm{O}_{3}$ was used as a powder for spraying. The resulting coating mainly consists of $\gamma-\mathrm{Al}_{2} \mathrm{O}_{3}$. This is due to the fact that the powder of $\mathrm{Al}_{2} \mathrm{O}_{3}$ can undergo several modifications under the influence of high temperatures [29,30].

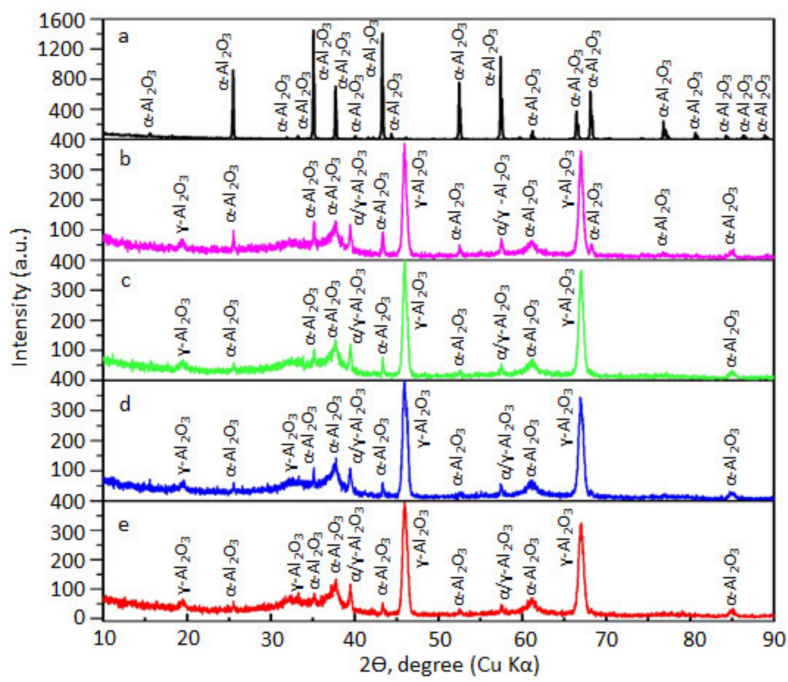

Figure 7. Diffraction pattern of aluminum oxide coating depending on the filling of the barrel: $\mathrm{Al}_{2} \mathrm{O}_{3}$ Powder (a), 53\% (b), 58\% (c), 63\% (d), 68\% (e).

Figure 7a-e shows the results of X-ray phase analysis of $\mathrm{Al}_{2} \mathrm{O}_{3}$ powder before detonation injection and when filling the barrel from $53 \%$ to $68 \%$. Figure 7 a shows that alumina oxide in powder form consists of a single $\alpha-\mathrm{Al}_{2} \mathrm{O}_{3}$ phase. Figure 7 shows that with an increase in the filling of the barrel with gas from $53 \%$ to $68 \%$, the content of $\gamma-\mathrm{Al}_{2} \mathrm{O}_{3}$ phase in the coating increases, while the content of $\alpha-\mathrm{Al}_{2} \mathrm{O}_{3}$ phase decreases. In our opinion, it can be assumed that the $\gamma-\mathrm{Al}_{2} \mathrm{O}_{3}$ phase is formed when the barrel is filled by $68 \%$ due to an increase in the explosion temperature and the impact of a shock wave during flight along the barrel and subsequent spraying onto the surface. Since, it is known that when the temperature rises to $950-1250{ }^{\circ} \mathrm{C}, \gamma-\mathrm{Al}_{2} \mathrm{O}_{3}$ turns into thermodynamically stable $\alpha-\mathrm{Al}_{2} \mathrm{O}_{3}$. This transformation can proceed directly or through intermediate phases such as $\delta$ - and $\theta-\mathrm{Al}_{2} \mathrm{O}_{3}[31,32]$.

Figure 8 shows the results of tribological tests of $\mathrm{Al}_{2} \mathrm{O}_{3}$ coatings by the ball-disk method. The wear resistance of the coatings was characterized by the volume of wear. Figure 8 shows that the samples have different values of the volume of wear depending on the degree of barrel filling. In this case, the wear gradually increases with an increase 
in the degree of filling. The coating obtained when the barrel is filled to $53 \%$ has a high wear resistance. Thus, based on X-ray diffraction analysis, it can be assumed that an increase in the volume fraction of $\alpha-\mathrm{Al}_{2} \mathrm{O}_{3}$ phase in coatings leads to an increase in their wear resistance. This is because $\alpha-\mathrm{Al}_{2} \mathrm{O}_{3}$ has a number of features, including low density, relatively high melting point, excellent corrosion and wear resistance, and high strength at high temperatures [33-35].

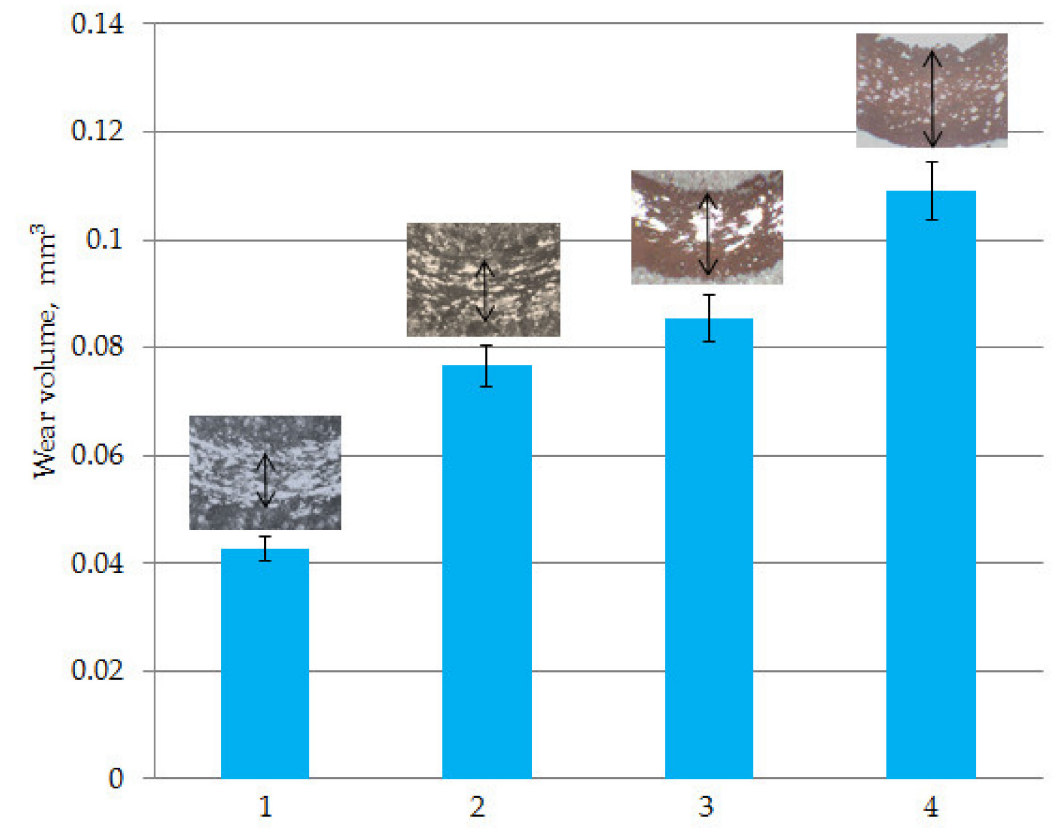

Figure 8. Results of tribological tests of $\mathrm{Al}_{2} \mathrm{O}_{3}$ coatings according to the "ball-disk" scheme: $53 \%$ (1), $58 \%(2), 63 \%(3), 68 \%(4)$.

Figure 9 shows the graphs of the friction coefficients of coatings obtained when filling the barrel by $53 \%, 58 \%, 63 \%$ and $68 \%$. In [36] the tribological properties of the $\mathrm{Al}_{2} \mathrm{O}_{3}$ coating obtained by the plasma method using $\mathrm{ZrO}_{2}, \mathrm{Si}_{3} \mathrm{~N}_{4}, \mathrm{Al}_{2} \mathrm{O}_{3}$ and stainless steel balls (1Cr18Ni9Ti) with a diameter of $6 \mathrm{~mm}$. It was noted that the coefficient of friction was $\mu \approx 0.55-0.6$ with $\mathrm{ZrO}_{2}$, with $\mathrm{Si}_{3} \mathrm{~N}_{4} \mu \approx 0.5-0.55$, with $\mathrm{Al}_{2} \mathrm{O}_{3}$ ball $\mu \approx 0.6-0.65$, with stainless steel ball (1Cr18Ni9Ti) $\mu \approx 0.7-0.8$. In [37] a steel ball 100Cr6 was used to study the friction and wear resistance of $\mathrm{ZrO}_{2}-\mathrm{Al}_{2} \mathrm{O}_{3}$-based coatings obtained by air-plasma injection. In our study, a steel ball 100Cr6 was used, respectively, the value of the coefficient of friction was in the range $\mu \approx 0.52-0.59$, the coefficient of friction was observed in the coating when filling the barrel with gas at least $53 \%$. The coefficients of friction of all coatings obtained when filling the barrel by $53 \%, 58 \%$ and $68 \%$ have the same values and are $\mu=0.52 \pm 0.01$. The coating obtained when filling the barrel by $63 \%$ has a high coefficient of friction $\mu=0.59 \pm 0.01$ in comparison with other samples. Apparently, this is due to the roughness and porosity of the coatings.

Figure 10 shows the change in the micro-hardness of the coating. Modifications of $\alpha$ and $\gamma$-phases have different values of physical and mechanical properties. Modifications of $\alpha-\mathrm{Al}_{2} \mathrm{O}_{3}$ have high hardness and wear resistance, while $\gamma-\mathrm{Al}_{2} \mathrm{O}_{3}$ is relatively elastic and provides high adhesion to the substrate [38]. Analysis of the effect of phase composition on the physicochemical and mechanical characteristics of plasma detonation coatings made of aluminum oxide shows that an increase in the stable $\gamma$-phase, as well as other (metastable) phases reduces the hardness, wear resistance and corrosion resistance of the coating. In addition, the maximum hardness of the coating obtained by plasma detonation is $1.98 \mathrm{Gpa}$, Thus, the use of plasma-detonation technology for spraying coatings made of $\mathrm{Al}_{2} \mathrm{O}_{3}$ allows to obtain dense multi-phase coatings with good adhesion to the substrate (due to damping of low-temperature stable and metastable modifications) and high physical and mechanical 
properties (due to high $\alpha$-phase composition) [13]. Based on these analyzes, based on the results of our study, we conclude that the mechanical and tribological properties increased due to the increase in $\alpha-\mathrm{Al}_{2} \mathrm{O}_{3}$, and the adhesion strength may improve due to the $\gamma-\mathrm{Al}_{2} \mathrm{O}_{3}$ phase. In [28] reported that the hardness of the $\mathrm{Al}_{2} \mathrm{O}_{3}$ coating obtained increased from 10.87 to $16.33 \mathrm{GPa}$ by reducing the delay time between shots during a detonation explosion from 1 to $0.25 \mathrm{~s}$. In [17] reported that the hardness of the $\mathrm{Al}_{2} \mathrm{O}_{3}$ coating increases from 7.86 to $11.08 \mathrm{GPa}$ as the thickness increases from 250 to $1100 \mu \mathrm{m}$. In [35] reported that the microhardness of $\mathrm{ZrO}_{2}-\mathrm{Al}_{2} \mathrm{O}_{3}$-based coatings obtained by air-plasma injection was in the range of 8.06-9.11 GPa. The micro-hardness of the obtained coatings, depending on the filling with gas, was at $53 \%-20.6 \pm 0.3 \mathrm{GPa}, 58 \%-16.3 \pm 0.15 \mathrm{GPa}, 63 \%-17.9 \pm 0.25 \mathrm{GPa}$, and at $68 \%-18.16 \pm 0.27 \mathrm{GPa}$. At the same time, the highest value of micro-hardness was observed at $53 \%$ filling. An increase in the micro-hardness of coatings is associated with an increase in the $\alpha-\mathrm{Al}_{2} \mathrm{O}_{3}$ phase. $\gamma-\mathrm{Al}_{2} \mathrm{O}_{3}$ has a lower hardness and mechanical resistance than $\alpha-\mathrm{Al}_{2} \mathrm{O}_{3}$.

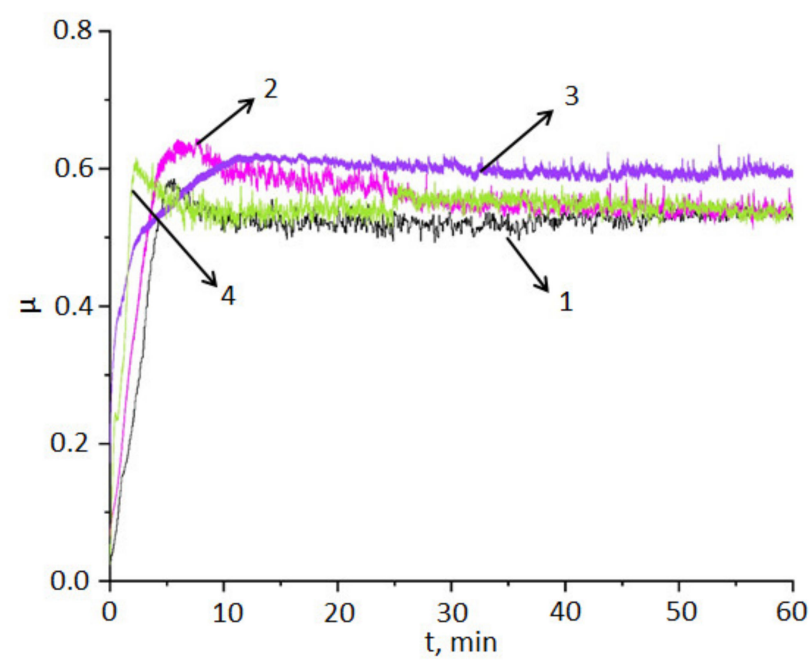

Figure 9. Results of tribological studies of $\mathrm{Al}_{2} \mathrm{O}_{3}$ coating depending on the filling of the barrel with gas: $53 \%(1), 58 \%(2), 63 \%(3), 68 \%(4)$.

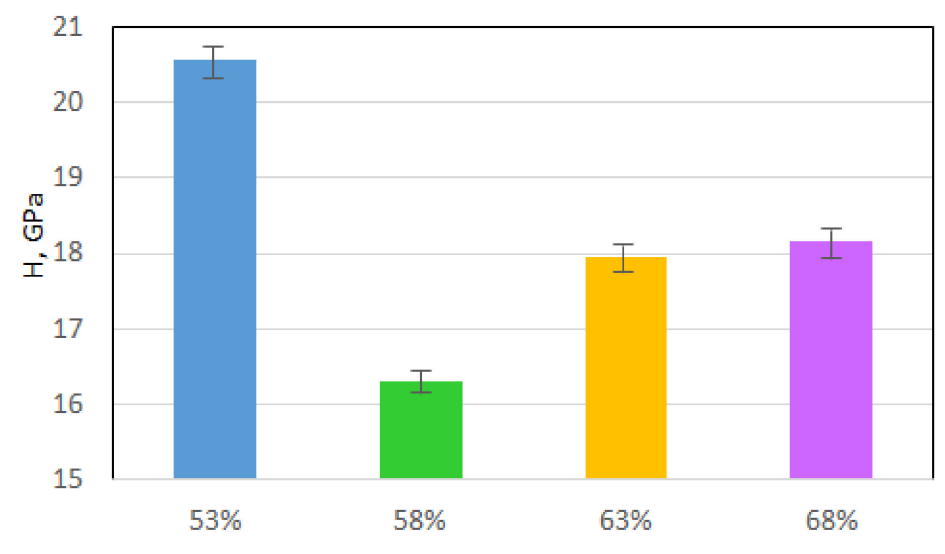

Figure 10. Changes in the micro-hardness of the surface layer of an aluminum oxide coating depending on the filling of the barrel with gas.

\section{Conclusions}

Thus, it can be concluded that the detonation spraying method can be used to obtain coatings based on $\mathrm{Al}_{2} \mathrm{O}_{3}$ with specified structure and properties. During detonation spraying of $\mathrm{Al}_{2} \mathrm{O}_{3}$ powder, the resulting coating consists of $\alpha-\mathrm{Al}_{2} \mathrm{O}_{3}$ and $\gamma-\mathrm{Al}_{2} \mathrm{O}_{3}$, and their volume fraction strongly depends on the technological mode of spraying. It is clear that the 
amount of wear gradually decreases with increasing barrel filling. The coating obtained when the barrel is filled to $53 \%$ has a high wear resistance. Based on X-ray diffraction analysis, it was found that an increase in the volume fraction of $\alpha-\mathrm{Al}_{2} \mathrm{O}_{3}$ phases in coatings leads to an increase in their wear resistance. It is necessary to increase the volume fraction of $\alpha-\mathrm{Al}_{2} \mathrm{O}_{3}$ to ensure high hardness and wear resistance of the detonation $\mathrm{Al}_{2} \mathrm{O}_{3}$ coating. In further studies, it is planned to obtain a gradient coating based on $\mathrm{Al}_{2} \mathrm{O}_{3}$, in which the structure and properties gradually change with depth.

Author Contributions: Designed the experiments, N.K., B.R., and S.K.; performed the experiments, N.K. and A.A.; analyzed the data, B.R., N.K., G.Y., and D.Y.; wrote, reviewed and edited the paper, N.K., B.R. All authors have read and agreed to the published version of the manuscript.

Funding: This paper was performed within the grant financing of scientific research of the Committee of Science of the Ministry of Education and Science of the Republic of Kazakhstan. Grant AP08857579.

Institutional Review Board Statement: Not applicable.

Informed Consent Statement: Not applicable.

Data Availability Statement: Data is contained within the article.

Conflicts of Interest: The authors declare that there is no conflict of interest regarding the publication of this manuscript.

\section{References}

1. Rakesh, G.; Singh, S.B.; Grewal, J.S. Surface engineering and detonation gun spray coating. Int. J. Eng. Stud. $2010,3,351-357$.

2. Dhakar, B.; Namdeo, A.; Chatterjee, S.; Sabiruddin, K. Heat treatment of plasma sprayed alumina-chromia composite coatings. Surf. Eng. 2018, 34, 737-746. [CrossRef]

3. Bannier, E.; Vincent, M.; Rayon, E.; Benavente, R.; Salvador, M.D.; Sanchez, E. Effect of $\mathrm{TiO}_{2}$ addition on the microstructure and nanomechanical properties of $\mathrm{Al}_{2} \mathrm{O}_{3}$ suspension plasma sprayed coatings. Appl. Surf. Sci. 2014, 316, 141-146. [CrossRef]

4. Vignesh, S.; Shanmugam, K.; Balasubramanian, V.; Sridha, K. Identifying the optimal HVOF spray parameters to attain minimum porosity and maximum hardness in iron based amorphous metallic coatings. Def. Technol. 2017, 13, 101-110. [CrossRef]

5. He, L.; Tan, Y.; Wang, X.; Xu, T.; Hong, X. Microstructure and wear properties of $\mathrm{Al}_{2} \mathrm{O}_{3}-\mathrm{CeO}_{2} / \mathrm{Ni}$ - base alloy composite coatings on aluminium alloys by plasma spray. Appl. Surf. Sci. 2014, 314, 760-767. [CrossRef]

6. Zhang, S.-H.; Cho, T.-Y.; Yoon, J.-H.; Fang, W.; Song, K.-O.; Li, M.-X.; Joo, Y.-K.; Lee, C.G. Characterization of microstructure and surface properties of hybrid coatings of WC-CoCr prepared by laser heat treatment and high velocity oxygen fuel spraying. Mater. Char. 2008, 10, 1412-1418. [CrossRef]

7. Ulianitsky, V.Y.; Batraev, I.S.; Shtertser, A.A.; Dudina, D.V.; Bulina, N.V.; Smurov, I. Detonation spraying behaviour of refractory metals: Case studies for moand Ta-based powders. Adv. Powder Technol. 2018, 29, 1859-1864. [CrossRef]

8. Gallyamov, A.A.; Nenashev, M.V.; Ibatullin, I.D.; Murzin, A.Y. Application detonation coatings to design a new metal cutting tool. Trans. IMF 2018, 6, 290-294. [CrossRef]

9. Thirumalaikumarasamy, D.; Shanmugam, K.; Balasubramanian, V. Corrosion performance of atmospheric plasma sprayed alumina coatings on AZ31B magnesium alloy under immersion environment. J. Asian Ceram. Soc. 2014, 4, 403-415. [CrossRef]

10. Vikas, C.; Singh, S.B.; Puri, D.; Prakash, S. Performance of plasma sprayed nanostructured and conventional coatings. J. Aust. Ceram. Soc. 2008, 2, 56-62.

11. Upadhyay, R.; Tailor, S.; Shrivastava, S.; Modi, S.C. High performance thermal-sprayed WC-10Co-4Cr coatings in narrow and complex areas. Surf. Eng. 2018, 34, 412-421. [CrossRef]

12. Sundarajan, G.; Sen, D.; Sivakumar, G. The tribological behaviour of detonation sprayed coatings: The importance of coating process parameters. Wear 2005, 258, 377-391. [CrossRef]

13. Pogrebnyak, A.D.; Tyurin, Y.N.; Ivanov, Y.F.; Kobzev, A.P.; Kulmentieva, O.P.; Ilyashenko, M.I. Obtaining and investigation of the structure and properties of plasma-detonation coatings from $\mathrm{Al}_{2} \mathrm{O}_{3}$. Lett. J. Tech. Phys. 2000, 21, 53-60.

14. Saravanan, P.; Selvarajan, V.; Rao, D.S.; Joshi, S.V.; Sundararajan, G. Influence of process variables on the quality of detonation gun sprayed alumina coatings. Surf. Coat. Technol. 2000, 123, 44-54. [CrossRef]

15. Rakhadilov, B.K.; Buytkenov, D.B.; Kakimzhanov, D.; Kozhanova, R.S.; Bektasova, G.S. The effect of detonation spraying on the phase composition and hardness of $\mathrm{Al}_{2} \mathrm{O}_{3}$ coatings. Eurasian J. Phys. Func. Mater. 2020, 2, 160-166. [CrossRef]

16. Rakhadilov, B.K.; Buitkenov, D.B.; Tuyakbaev, B.T.; Sagdoldina, Z.B.; Kenesbekov, A.B. Structure and properties of detonation coatings based on titanium carbosilicide. Key Eng. Mater. 2019, 821, 301-306.

17. Rakhadilov, B.; Kantay, N.; Sagdoldina, Z.; Erbolatuly, D.; Bektasova, G.; Paszkowski, M. Experimental investigations of $\mathrm{Al}_{2} \mathrm{O}_{3}-$ and $\mathrm{ZrO}_{2}$-based coatings deposited by detonation spraying. Mater. Res. Express. 2021, 8, 1-12. [CrossRef]

18. Rakhadilov, B.; Maulet, M.; Abilev, M.; Sagdoldina, Z.; Kozhanova, R. Structure and tribological properties of Ni-Cr-Al-based gradient coating prepared by detonation spraying. Coatings 2021, 2, 1-14. 
19. Tian, H.L.; Guo, M.Q.; Wang, C.L.; Tang, Z.H.; Cui, Y.J. Tribological behaviour of a self-lubricated GO/WC-12Co thermal spray coating. Surf. Eng. 2018, 34, 762-770. [CrossRef]

20. Dudina, D.V.; Batraev, I.S.; Ulianitsky, V.Y.; Bulina, N.V.; Korchagin, M.A.; Lomovsky, O.I. Detonation spraying of Ti-Al Intermetallics: Phase and micro-structure developments of the coatings. Mater. Manuf. Process. 2015, 30, 724-729. [CrossRef]

21. GOST 4986-79. Cold-Rolled Band from Corrosion-Resistant and Heat-Resistant Steel; USSR State Committee for Standards: Moscow, Russia, 1979.

22. Smurov, I.; Ulianitsky, V. Computer controlled detonation spraying: A spraying process upgraded to advanced applications. Surf. Eff. Cont. Mech. 2011, 71, 265-276.

23. Ulianitsky, V.Y. Physical foundations of detonation spraying. Ph.D. Thesis. Institute of Hydrodynamics. M. A. Lavrentieva Siberian Branch of the Russian Academy of Sciences, Novosibirsk, Russia, 2001.

24. Rakhadilov, B.; Buitkenov, D.; Rakhadilov, M. Tribological properties of $\mathrm{AI}_{2} \mathrm{O}_{3}$ coatings obtained by detonation. Mater. Sci. Eng. 2021, 1079, 1-7.

25. GOST 2789-73. Surface Roughness. Parameters and Characteristics; Russian GOST: Moscow, Russia, 1975.

26. GOST 9450-76. Measurements Microhardness by Diamond Instruments Indentation; Russian GOST: Moscow, Russia, 1976.

27. ASTM G133-95. Standard Test Method for Linearly Reciprocating Ball-on-Flat Sliding Wear; ASTM International: West Conshohocken, PA, USA, 1995.

28. ASTM G99-05. Standard Test Method for Wear Testing with a Pin-on-Disk Apparatus; ASTM International: West Conshohocken, PA, USA, 2005

29. Mayya, P.; Marina, K.; Marii, A.; Maxim, Y.; Vseslav, N.; Vyacheslav, S.; Yurii, T.; Oleg, K.; Nikolay, V. Effect of heat treatment of the alumina powder on the microstructure and properties of coatings. In MATEC Web of Conferences; EDP Sciences: Tomsk, Russia, 2005.

30. Kantay, N.; Kasmamytov, N.; Rakhadilov, B.; Plotnikov, S.; Paszkowski, M.; Kurbanbekov, S. Influence of temperature on structural-phase changes and physical properties of ceramics on the basis of aluminum oxide and silicon. Mater. Test. 2020, 62, 716-720. [CrossRef]

31. Shoja, S.; Alm, O.; Norgren, S.; Andrén, H.O.; Halvarsson, M. Calculated and experimental Schmid factors for chip flow deformation of textured CVD $\alpha$-alumina coatings. Surf. Coat. Technol. 2021, 412, 126991. [CrossRef]

32. Algatti, M.A.; Santos, C.N.; Mota, R.P.; De Campos, E.; Lucena, E.F.; Machida, M.; Melo, F.C.L. Characterization of $\mathrm{SiC}_{\text {and }} \mathrm{Al}_{2} \mathrm{O}_{3}$ ceramics exposed to nitrogen ions from inverse-Z pinch plasma discharge. In Proceedings of the 16th Latin American Workshop on Plasma Physics (LAWPP), Mexico City, Mexico, 4-8 September 2017; pp. 5-11.

33. Kaya, G.; Gunhan, B.; Ozer, I.O.; Poyraz, H.B. Production of $\mathrm{TiO}_{2}$ coated $\alpha-\mathrm{Al}_{2} \mathrm{O}_{3}$ platelets by flame spray pyrolysis and their characterization. Ceram. Int. 2020, 46, 25512-25519. [CrossRef]

34. Zhu, C.; Zhang, W.; Wang, L.; Ning, Z.; Feng, Y.; Feng, K.; Liao, J.; Yang, Y.; Liu, N.; Yang, J. Effect of thermal cycles on structure and deuterium permeation of $\mathrm{Al}_{2} \mathrm{O}_{3}$ coating prepared by MOD method. Fusion Eng. Des. 2020, 159, 111750. [CrossRef]

35. Cheng, J.; Ge, Y.; Wang, B.; Zhang, L.; Hu, X.; Hong, S.; Liang, X.; Zhang, X. Microstructure and Tribocorrosion behavior of $\mathrm{Al}_{2} \mathrm{O}_{3} / \mathrm{Al}$ composite coatings: Role of $\mathrm{Al}_{2} \mathrm{O}_{3}$ addition. J. Therm. Spray Technol. 2020, 29, 1741-1751. [CrossRef]

36. Deng, W.; Shuangjian, L.; Guoliang, H.; Xia, L.; Xiaoqin, Z.; Yulong, A.; Huidi, Z.; Jianmin, C. Comparative study on wear behavior of plasma sprayed $\mathrm{Al}_{2} \mathrm{O}_{3}$ coatings sliding against different counterparts. Ceram. Int. 2017, 43, 6976-6986. [CrossRef]

37. Ling, B.; Zhang, G.; Liao, H.; Coddet, C.; Ding, C. Friction and wear behavior of $\mathrm{ZrO}_{2}-\mathrm{Al}_{2} \mathrm{O}_{3}$ composite coatings deposited by air plasma spraying: Correlation with physical and mechanical properties. Sur. Coat. Technol. 2009, 203, 3235-3242. [CrossRef]

38. Bye, G.; Simpkin, G. Influence of $\mathrm{Cr}$ and $\mathrm{Fe}$ on formation of $\alpha-\mathrm{Al}_{2} \mathrm{O}_{3}$ from $\gamma-\mathrm{Al}_{2} \mathrm{O}_{3}$. J. Am. Ceram. Soc. 2006, 57, 367-371. [CrossRef] 